\title{
Service Quality of Hotels from Employee and Guest Perspectives
}

\author{
July Hera G. Salomon ${ }^{1}$ \\ ${ }^{1}$ Assistant Professor, Surigao del Sur State University, Philippines
}

\begin{abstract}
This paper examined the level of service quality of hotels in Tandag City, Surigao del Sur as perceived by both guests and hotel employees. Reviewed studies focused only on assessing the quality of service from the guest perspective or the employees on another study. Thus, it aimed to determine the significant difference between the level of service quality rendered by the employees and as perceived by the guests in one study. Assessment is based on the ten service quality determinants of Parasuraman and colleagues. The study employed descriptive quantitative research method and distributed survey questionnaires to 111 employees and 259 guests in identified accommodation establishments who are members of Tandag City Hotel and Restaurant Association (TCHARA). Establishment owners and managers were also interviewed to determine the profile of hotel industry. The employees provide high confidence on the safety and security that the hotel provides to their guests. The guests on the other hand, are greatly satisfied by the way the hotel employees treat them in a friendly manner. The agreement of both employees and guests on the adequacy issue of the hotel signifies that hotels need to improve the facilities and services they provide. It was also found out that there is a significant difference between the level of service quality as perceived by hotel employees and guests. A proposed development intervention program is recommended to serve as guide for hotel operators in enhancing service quality and improving employee skills to upkeep the changing demands of the guests and the industry.
\end{abstract}

Keywords: service quality, ten determinants of service quality)

\section{Introduction}

Quality service is the leading component that determines competitiveness and success in the hotel industry. Under the service sector, hotel industry, profited by the flourishing tourism, is now booming in macro perspective. However, guests and tourists also have higher demands of service wants and expectations. The key problem for these hotels to survive is how to attract and retain customers. In such manner, it is very important that the workforce and management under this industry understand the necessity of carrying out service quality. Once customers' requirements are clearly identified and understood, hotel operators are more likely to anticipate and fulfil their customers' needs and wants (Juwaheer \& Ross, 2003). The more these guests are satisfied, the greater chances they are to repeat the services received (Choi and Chu, 2001). While the reasons of guests may be due to personal and other factors, the ability to create a satisfactory experience and excellent hotel service mainly rest to a considerable degree within the hands of both management and hotel staff. Many scholars and business practitioners emphasized that service quality is needed for maintaining the business on top of the competitive market. In corresponding to market demands, establishments should understand what factors influence customer satisfaction and adopt it in the design and delivery of services. Satisfied customers are potential customers in any service business. This discussion was expanded by Bitner and Zeithaml (2003) which pointed out that there is an overpowering interest in service quality because researchers and the industry practitioners both believed that quality is a crucial attribute in any success of the organization. When the company does not manage to meet customer requirements and expectations, the delivery will be considered a service failure. Loizos and Lycourgos (2005) described that service quality should be approached from the customer's perspective because the success of services in hotels can be considered as a success of failure is determined through the eyes of the guests and the impact of experience. It was also important to note that they are the ones who actually receive the services of such employees. However, Butcher and Hefferman (2006) discussed the relationship between the customer and employees in the aspect of service quality. It was noted that employees play an important role in service delivery. 
Achieving and maintaining service quality among hotels provide many benefits such institution of customer satisfaction, development of the business image, and foundation to customer loyalty. It should be noted that service quality performance may be perceived differently to different people. Hotel guests may have higher standards on service thus showing lower perception on service quality than the hotel employees. As such, the owners, managers and employees avert chances to identify and correct deficiencies in service quality (AlAbabneh, 2017). Still, previous research Al-Ababneh (2016) emphasized employees' perceptions and responses on the service quality of the hotel to ensure that the information gained does not center on the views of one party only and would also provide more valuable information for hotel operators in improving service quality. As such, this study aims to determine the level of service quality in the hotel industry by not only considering the assessment and feedback of the customers but also considering the perspective of the employees and assess whether there is a significant difference.

Studying the quality of service in the hotel industry is of great importance for survival in the competition and gaining long term profit margin for the company through creating satisfied customers. If the management is aware of the important areas or dimensions of service quality that threatens customer satisfaction, they can easily handle and improve the specific factors in the service delivery to cope with the demands and expectations of the customers. The findings and recommendations of the study will lead to the development of an intervention program that will answer the gaps and deficiencies therein that hinders provision of quality service.

This research is anchored on studies and concepts on the use and measurement of service quality and the legalities concerning the hotel industry. In the study explained by Grönroos (1983, reviewed 2007), ten (10) determinants of service quality were identified. These were Tangibles, Access, Competence, Reliability, Courtesy, Security, Responsiveness, Credibility, Communication, and Understanding/Knowing the Customer. These determinants are sought to be important factors in assessing the quality of service in a service business. Each determinant encompasses different aspects that define every detail in service. These ten determinants of service quality were also identified by Parasuman, Zeithaml and Berry (1985) as the ten factors or components of the expressive service.

This study aims to identify the level of service quality of hotels in Tandag City, Philippines from the perspectives of the employees and guests. This paper hypothesized that there is no significant difference between the level of service quality from the hotel employees and guests' perspectives.

\section{Methodology}

Since the present study is concerned with the perspective comparison of both employees and guests, data derived through descriptive quantitative method was used. The study was conducted in eleven (11) accommodation establishments that are registered under the Tandag City Hotel and Restaurant Association (TCHARA). The respondents of the study were composed of two groups -the hotel employees and guests. Other key informants were the managers and/or operators of the hotels under study who filled in the necessary data about the establishment. Stratified proportional random sampling was used to collect data using the modified questionnaire adopted from several studies and literature from experts in research, academia and industry. Content analysis of the survey instrument was under validation of five experts in the industry and in the academe. To test the stability and consistency of the assessment tool, the survey instrument was also put under inter-rater reliability test. This was used to measure the degree of the different raters' assessment decisions upon agreement. Various methods for data analysis were applied to the set of survey variables. Computation on the weighted mean was used to determine the average responses from the survey. Likert Scale Technique was also utilized. In a Likert scale, the respondent is asked to respond to each of the statements in terms of several degrees, under the study, five degrees of agreement or disagreement. This scale is useful in providing adjectival ratings that will be quantified in the computation of the mean. To determine the significant difference between the level of service quality as perceived by hotel employees and guests, t-test was employed. 


\section{Results and Discussions}

Service quality is an important determinant of success in attracting repeat business for a hotel. This paper highlights on the assessment of service quality using the ten determinants.

Table I: Level of Service Quality

\begin{tabular}{|c|c|c|c|c|c|c|}
\hline \multirow[b]{2}{*}{ Service Quality Determinant } & \multicolumn{3}{|c|}{ Employee } & \multicolumn{3}{|l|}{ Guest } \\
\hline & $\begin{array}{l}\text { Weighte } \\
\text { d Mean }\end{array}$ & $\begin{array}{l}\text { Descriptive } \\
\text { Rating } \\
\end{array}$ & $\begin{array}{l}\text { Ran } \\
\mathbf{k}\end{array}$ & $\begin{array}{l}\text { Weighted } \\
\text { Mean }\end{array}$ & $\begin{array}{l}\text { Descriptive } \\
\text { Rating } \\
\end{array}$ & Rank \\
\hline The hotel has visually appealing buildings and facilities. & 4.36 & SA & 20 & 3.90 & A & 37 \\
\hline Personnel are well-dressed and neat. & 4.37 & SA & 18 & 3.75 & A & 49 \\
\hline The atmosphere and equipment are comfortable and appropriate. & 4.48 & SA & 4 & 4.04 & A & 12 \\
\hline Materials associated with the services are adequate and sufficient. & 4.38 & SA & 16 & 3.88 & A & 42 \\
\hline The service units of the hotel have adequate capacity. & 4.00 & A & 50 & 3.58 & A & 50 \\
\hline The service of the hotel is easily accessible by telephone. & 4.42 & SA & 9 & 3.88 & A & 42 \\
\hline Waiting time to receive services is not extensive. & 4.23 & SA & 32 & 3.85 & A & 46 \\
\hline The operating hours of hotel are convenient to all their guests. & 4.22 & SA & 34 & 4.03 & A & 17 \\
\hline It is easy to access to the hotel. & 4.19 & A & 41 & 4.08 & A & 5 \\
\hline Getting information about the facilities and services of the hotel is easy. & 4.17 & A & 44 & 3.89 & A & 39 \\
\hline The hotel is equipped with highly competent employees. & 4.17 & A & 44 & 3.80 & A & 48 \\
\hline The hotel staffs are knowledgeable of their products and services. & 4.25 & SA & 30 & 3.84 & A & 47 \\
\hline Employees provide skilled and efficient service. & 4.31 & SA & 26 & 3.96 & A & 28 \\
\hline Employees perform the services right the first time. & 4.18 & A & 42 & 4.09 & A & 4 \\
\hline The services of employees exceed hotel guests' expectations. & 4.21 & SA & 38 & 3.88 & A & 42 \\
\hline Employees reply readily in any concern of the guest. & 4.20 & A & 40 & 4.14 & A & 3 \\
\hline Employees are always available when needed. & 4.41 & SA & 12 & 4.01 & A & 21 \\
\hline Employees respond to requests quickly. & 4.32 & SA & 24 & 3.90 & A & 37 \\
\hline Employees check guest satisfaction. & 4.25 & SA & 30 & 3.92 & A & 33 \\
\hline Employees give prompt services. & 4.41 & SA & 12 & 4.07 & A & 6 \\
\hline The hotel provides service as promised. & 4.37 & SA & 18 & 4.02 & A & 18 \\
\hline Employees provide accurate information to the guests. & 4.33 & SA & 23 & 4.04 & A & 12 \\
\hline Employees perform services correctly. & 4.32 & SA & 24 & 3.91 & A & 34 \\
\hline Employees inform guests when the service is to be provided. & 4.30 & SA & 28 & 3.97 & A & 26 \\
\hline Guests can depend on the hotel employees. & 4.05 & A & 49 & 3.95 & A & 30 \\
\hline Employees always treat guests in a friendly manner. & 4.42 & SA & 9 & 4.19 & A & 1 \\
\hline Employees greet guests as soon as possible. & 4.43 & SA & 8 & 3.95 & A & 30 \\
\hline Employees show enthusiastic service. & 4.41 & SA & 12 & 3.98 & A & 24 \\
\hline Employees treat customer nicely regardless of customer's attire. & 4.14 & A & 47 & 3.89 & A & 39 \\
\hline Employees respect the guests. & 4.38 & SA & 16 & 4.06 & A & 8 \\
\hline Employees speak with guests by appropriate language. & 4.22 & SA & 34 & 4.02 & A & 18 \\
\hline Employees able to communicate with the guests effectively. & 4.21 & SA & 38 & 3.93 & A & 32 \\
\hline Employees explain the service itself to guests. & 4.23 & SA & 32 & 3.96 & A & 28 \\
\hline Employees explain how much the service will cost to the guests. & 4.31 & SA & 26 & 4.02 & A & 18 \\
\hline The hotel resolves guest complaints and compensates for the ... & 4.36 & SA & 20 & 4.00 & A & 22 \\
\hline The hotel employees have product knowledge of the hotel. & 4.22 & SA & 34 & 4.04 & A & 12 \\
\hline The hotel employees have the skills required to perform service. & 4.22 & SA & 34 & 3.89 & A & 39 \\
\hline The hotel serves consistent services. & 4.14 & A & 47 & 3.91 & A & 34 \\
\hline Food and beverages served are hygienic, adequate and sufficient. & 4.18 & A & 42 & 3.91 & A & 34 \\
\hline The hotel provides errorless payment system. & 4.15 & A & 46 & 4.06 & $\mathrm{~A}$ & 8 \\
\hline The hotel provides its guests a safe and secure place. & 4.53 & SA & 1 & 3.97 & A & 26 \\
\hline Employees instill confidence in guests. & 4.35 & SA & 22 & 3.98 & A & 24 \\
\hline Employees have high in-depth occupational knowledge. & 4.42 & SA & 9 & 3.88 & A & 42 \\
\hline Employees are concerned about customers' safety and privacy. & 4.45 & SA & 7 & 4.05 & A & 11 \\
\hline Guests and visitors can trust the employees of the hotel. & 4.30 & SA & 28 & 4.07 & A & 6 \\
\hline Employees have knowledge to provide information and assistance ... & 4.40 & SA & 15 & 4.04 & A & 12 \\
\hline Employees make guests the first priority. & 4.53 & SA & 1 & 4.15 & A & 2 \\
\hline Employees of the hotel understand the specific needs of guests. & 4.50 & SA & 3 & 3.99 & A & 23 \\
\hline Employees give guests individualized attention that makes them special. & 4.48 & SA & 4 & 4.06 & A & 8 \\
\hline The hotel provides flexibility in services according to guest demands. & 4.48 & SA & 4 & 4.04 & A & 12 \\
\hline
\end{tabular}

Legend: SA= Strongly Agree; A=Agree 
Table 1 presents the results on the level of service quality based on the following statements under the ten determinants. The findings revealed that most employees perceived that the hotel is a safe and secured place for the guests who avail the services therein. Safe and secure hotel accommodations in the hospitality industry are key players in its reputation and success as it is dependent mostly on guest relationship of such hotels (Chauhan, Shukla and Negi, 2018). These entities must properly provide for the maintenance of assets and protection of guests. The findings also revealed that the guests were mostly satisfied by the service of the employees in treating them in a friendly manner. Courtesy to customers, as emphasized by Wagner (2010), makes a business organization stand out from the others. Simple but genuine courtesies will strengthen the relationship between the organization and the customers. Loyalty, repeat business and referrals will then surely be garnered. Good manners and courtesies will make the guests feel that their presence is valued and appreciated. Hence, guests will base their judgements and observations based on how they were treated within their entire stay. Both employees and guests perceived that the hotel doesn't have adequate capacity in rooms, dining area and others. They both agreed that hotels in Tandag City have to improve the carrying capacity and adequacy for the convenience of both guests and employees. The physical surroundings in the establishment always affect guest expectations in the preliminary marketing stage, and customer experiences during their visit to the hotel (Thapa, 2007)

Table II: Significant Difference of Service Quality between Employees and Guests

\begin{tabular}{|l|l|l|l|l|}
\hline Service Quality Determinant & t & v & Decision & Conclusion \\
\hline Tangibles & 5.815 & 250.58 & \\
\hline Access & 3.242 & 252.18 & \\
\hline Competence & 3.727 & 245.22 & \\
\hline Responsiveness & 3.872 & 233.02 & \multirow{3}{*}{ Ho is rejected Significant } \\
\hline Reliability & 3.731 & 214.90 & \\
\hline Courtesy & 4.433 & 244.07 & \\
\hline Communication & 3.359 & 225.48 & \\
\hline Credibility & 2.507 & 195.34 & \\
\hline Security & 5.354 & 208.96 & \\
\hline Understanding the Customer & 5.478 & 247.37 & \\
\hline Legend: & & & \\
\hline
\end{tabular}

Legend: $\mathrm{t}=\mathrm{t}$-value, $\mathrm{v}=$ degree of freedom

The data revealed there is a significant difference in all the service quality determinants as perceived by hotel employees and guests. This implies that guests and employees have different perceptions on the quality of service the hotels are providing in Tandag City. More so, guests perceived that there is still a need for the establishment to improve the current hotel service.

\section{Conclusions and Recommendations}

Based on the findings, the employees provide high confidence on the safety and security that the hotel provides to their guests. The guests on the other hand, are greatly satisfied by the way the hotel employees treat them in a friendly manner. The agreement of both employees and guests on the adequacy issue of the hotel signifies that hotels need to improve the facilities and services they provide.

It is recommended that the management may conduct employee trainings and product orientation to enhance the knowledge and skills of the employees ensuring that all service quality determinants/factors be improved to upgrade the quality of current service delivery.

It is also suggested that there will be a development intervention program for this will provide all the hotel owners/operators the guide in conducting employee trainings, seminars and other strategies basing on the weak points of the employees as evaluated by both employees and guests. Henceforth, such development endeavors would receive most positive results and outcomes.

Similar studies may also be conducted in other cities and/or municipalities in Surigao del Sur. Other places 
can also assess the service quality in the local hotel setting so that if similar problems and deficiencies are found, joined efforts may be exerted to improve the level of service quality in all accommodation establishments in the province. For future researches, it is highly recommended that an inclusion of expert's opinion survey for triangulation purpose and reliability of data.

\section{Acknowledgements}

The research paper is a completed thesis of the researcher. Thus, she wished to thank her adviser Dr. Dagondon and to the panel members of Surigao del Sur State University-Graduate School. Grattitude is also extended to those who helped with the paper -Aldrich, Jon Al, Engr. Alex, Ma'am Jennilyn, Ma'am Roullete, Dhen,Ma'am Irish, Sir Kirk, Sir Jun, Sir Kian, and Rinz. Lastly, the cooperation of both the hotel management and their guests under survey is highly recognized.

\section{References}

[1] M. Al-Ababneh (2017) Service Quality in the hospitality Industry. j Tourism Hospitality 6: e133 doi: 10.4172/2167$0269.1000 \mathrm{e} 133$ https://doi.org/10.4172/2167-0269.1000e133

[2] M. Al-Ababneh (2016) Employee's perspectives of service quality in hotels, Research in Hospitality Management, 6(2), 189-194, DOI: 10.1080/22243534.2016.1253287

https://doi.org/10.1080/22243534.2016.1253287

[3] M. Bitner and V. Zeithaml, Service Marketing, 3rd edition. New Delhi:Tata MCGraw Hill, 2003.

[4] K. Butcher and T. Hefferman (2006). "A Social Regard; a link between waiting for service and service outcomes. International Journal of Hospitality Management, 25(1), 34-53.

https://doi.org/10.1016/j.ijhm.2004.12.006

[5] A. Chauhan, A. Shukla and P. Negi (2018). Safety and security measures adopted by the hotels and their impact on customer relationship management. International Journal of Research -Granthaalayah 6(1), 118-125. https://doi.org/10.5281/zenodo.1162714.

[6] T. Choi and R. Chu (2001) Determinants of hotel guests' satisfaction and repeat patronage in the Hong Kong hotel industry. International Journal of Hospitality Management, 20(3), 277-297.

https://doi.org/10.1016/S0278-4319(01)00006-8

[7] C. Gronroos, Strategic Management and Marketing in the Service Sector, Swedish School of Economics and Business Administration, Helsingfors, Report No. 83-104, 1983.

[8] T. Juwaheer and D. Ross (2003) "A study of hotel guest perceptions in Mauritius", International Journal of Contemporary Hospitality Management, Vol. 15 Issue: 2, pp.105-115, https://doi.org/10.1108/09596110310462959 https://doi.org/10.1108/09596110310462959

[9] C. Loizos and H. Lycourgos. (2005) “A Customer's Expectation and Perception of Hotel Service Quality in Cyprus.” Hospitality Review, 23(2), Article 5. Available at: http://digitalcommons.fiu.edu/hospitalityreview/vol23/iss2/5

[10] A. Parasuman, V. Zeithaml, and L. Berry (1985). A conceptual model of service quality and its implications for future research. The Journal of Marketing, 41-50.

https://doi.org/10.1177/002224298504900403

[11] D. Thapa, "Hotel Lobby Design: Study of Parameters of Attraction," M.S. thesis, Graduate School, Texas tech University, Texas, 2007.

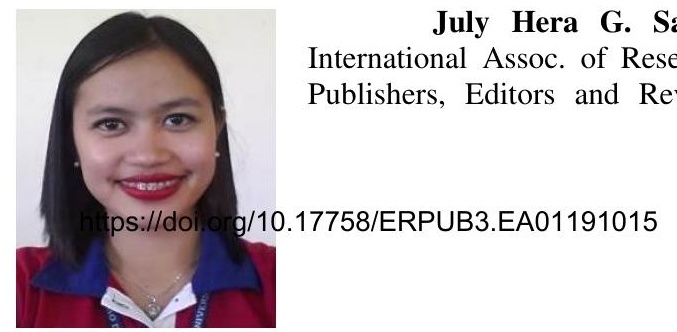

July Hera G. Salomon is a member of Asian Assoc. for Interdisciplinary Research (AAIR), International Assoc. of Research Ethics Across Disciplines (IAREAD), International Association of Scholarly Publishers, Editors and Reviewers Inc. (IASPER), Asian Society for Teachers of Research (ASTR), and 
International Association of Multidisciplinary Research (IAMURE). She graduated with Bachelor of Science in Hotel and Restaurant Management at Mindanao State University, Marawi City as Magna cum laude. She is completing her Doctor in Business Administration degree at Cebu Institute of Technology-University, Cebu City under the Commission on Higher Education (CHED) scholarship.

She is an Assistant Professor at Surigao del Sur State University, Main Campus, Tandag City. She was one of the researchers granted under the Department of Interior and Local Government (DILG) technical assistance program for LRIs on the utilization of CSIS results. She is also a recipient of the $1^{\text {st }}$ Department of Tourism (DOT) Tourism Research Grant 2018. Her research interests involve hospitality and tourism management, service quality, food tourism and tourism potentials. 